\title{
THE ROLE OF PRODUCTIVITY GROWTH IN AGRICULTURAL PRODUCTION DEVELOPMENT IN THE CENTRAL AND EASTERN EUROPE COUNTRIES AFTER 1991
}

\author{
Ludwik Wicki ${ }^{1}$ \\ ${ }^{1}$ Faculty of Economic Sciences, Warsaw University of Life Sciences - SGGW, Poland
}

\begin{abstract}
The land resources available for agriculture are limited. The global population is growing constantly, and so is demand for food. Increase in agricultural production can be achieved either through intensification of production or through technological progress. In the recent decades, increase in global agricultural production has been achieved mainly thanks to increase in effectiveness of production factors. The objective of this study is to compare changes in agricultural production in the selected new Member States of the EU after year 1991 and to determine the significance of TFP in production increase. The analysed period encompassed years 1991-2014; source data published by USDA were used. It was found that after the systemic transformation, a significant decrease in agricultural production - even to $40 \%$ - was recorded. This was due to reduction of the area of farming land, limiting of use of production factors and their reduced productivity. In the following years, agricultural production in the countries examined increased notwithstanding further limitation of inputs. This was due to gradual increase in factor productivity. In the examined period, increase in TFP almost entirely balanced off the decrease in production inputs and limitation of production area. In 2014, compared to 1991, inputs in some countries decreased even by $50 \%$, while production was reduced by no more than $30 \%$. The strongest increase in factor productivity was achieved in Latvia (38\%), Poland (26\%) and Estonia (24\%); nevertheless, in all of the countries analysed except for Poland, increase in production was due only to increase in TFP. In Poland, this process was accompanied also by intensification of production. Increase in production factor productivity is the key variable that generates increase in agricultural production, also under the conditions of limitation of farming land and extensification of agricultural production.
\end{abstract}

Key words: total factor productivity, technological change, land substitution, development barriers, economy transition

JEL code: Q11, Q16, P25

\section{Introduction}

Increase in agricultural productivity is one of the key factors that make it possible - now and in the future - to ensure the sufficient quantity of food for the growing global population. Thanks to increase in agricultural productivity after the second World War, food has become much more accessible and cheaper. According to Fuglie et al. (2012), since year 1900, real food prices have dropped by $1 \%$ per annum, while the global population increased in this period from 1.7 to 7 billion people. Only in the short period after year 2000, the decrease in food prices somewhat slowed its pace, and it is impossible to predict whether this trend will be maintained over the longterm perspective.

The main type of activity, leading to technological change in agriculture, is agricultural R\&D, conducted for the purpose of development of new production technologies and better varieties, animal races and machines. An important role is played by research associated with management of land and water in agriculture. Some of the new technologies, such as genetically modified organisms (GMO) are not widely used due to the associated controversies and prohibitions.

Increase in agricultural productivity can be achieved by increasing land resources, production inputs and by introduction of technological change. Increase in agricultural productivity in the last 20 years was mainly due to technical progress, and its significance tended to increase over time (Fig. 2). Economists of agriculture, studying the causes of increase in agricultural productivity, point to two key growth factors: almost $70 \%$ of this growth is due to increased productivity, while only a small part - due to increase in production inputs. This dominant significance of technological change is due to many decades of expenditures for research and development in 
agriculture (Alston et al., 2010; Gardner, 2002; Huffman and Evenson, 1993; Ruttan, 2002; Wang et al., 2015a). It has also been indicated that increase in agricultural productivity in the USA after year 1950 was significantly correlated with increase in TFP (total factor productivity), while no significant correlation was found between the level of production inputs and the size of agricultural production (Fuglie et al., 2017). For developing countries, there is a significant gap in achievement of land productivity and work in agriculture, which is several decades long. For the former Eastern bloc countries, this delay was estimated to be about 30 years, and for other European countries about 15 years (Fuglie et al., 2012).

The factors that determine the possibility and pace of progress transfer and then - increase in agricultural productivity include economic and social factors, as well as those associated with the farm area structure. Farms characterized by lower economic strength and small scale of production encounter both the barrier of lack of funds to introduce technological change and the barrier of accessibility of solutions, appropriate for small farms. The most neutral to production scale is biological progress - however, the same does not apply to mechanization or organization (Wicki, 2010).

Achievement of higher productivity in agriculture requires a good professional background (education) of producers (Kesti, 2011), as in most cases, changes must be introduced in several areas at the same time, such as introduction of new varieties of plants or races of animals, accompanied by changes in the production techniques, as otherwise productivity increase cannot be achieved (Dudek and Wicki, 2009). Lack of complex introduction of new technologies leads to emergence and maintaining of a significant productivity gaps even between countries or regions within the area o a single country (Wicki, 2016a). In more developed countries, productivity increase is currently achieved mainly thanks to biotechnology (Stevenson et al., 2013; Wicki, 2008; Wicki, 2017b), in less developed ones, mechanization progress is still of key significance (Pawlak, 2010).

Farm size and area structure are barriers that prevent progress and productivity increase (Czyzewski at al., 2016; Piwowar, 2017). As land concentration increases, changes are implemented at a higher pace (Du et al., 2018; Esposti, 2011; Filipiak, 2014; Wysokinski et al., 2015). In the case of large farms, this is economically viable due to their strong associations with the surrounding environment and a stronger response to market factors (Franc-Dabrowska, 2013; Golebiewska, 2009; Golebiewska, 2011; Kasztelan, 2009). As a result, large farms achieve higher productivity of production factors. In the first lace, mechanization of production processes leads to increase in productivity of labour, then - land and equity (Czyzewski and Kulyk, 2014; Czyzewski and Staniszewski, 2017; Golebiewski, 2013; Wicki, 2016b). On the other hand, higher agricultural productivity leads to an increase in land prices (Czyzewski et al., 2017), thus limiting land concentration and further development of productivity.

One of the most important factors in introduction of progress is the pricing mechanism. Favourable price correlations lead to a relatively greater pace of increase in productivity in selected agricultural sectors (Czyzewski at al., 2015) in accordance with the mechanism described by Hayami and Ruttan (1969). Thus, those sectors, in which higher production effectiveness is recorded, tend to develop more quickly (Wicka at al., 2016).

A very significant role in acceleration of changes in agricultural productivity is played by the state policy, and in the EU - also the common agricultural policy. Financing of research, focus on environmental protection, including reduction in emission of greenhouse gases or provision of other 
public goods, such as animal welfare, may limit the dynamics of growth of agricultural production (Danilowska, 2015; Grontkowska and Gebska, 2017; Lenerts et al., 2017). Similarly, changes in agriculture may be slowed down by support provided for small farms or aiming at limitation of production surplus, as well as supporting of development of new directions in production, such as biofuel production (Rubins et al., 2017; Wicki, 2017a). In most of the developed countries, also in Europe, there is a tendency to support increase in agricultural productivity on the basis of special governmental programs (Oliynyk, 2012; Orlykovskyi et al., 2016; Orlykovskyi et. al., 2017; Wicki 2017c). Moreover, within the framework of the so-called smart specializations, some of the European Union Member States have struggled to increase agricultural productivity (Gemma and Bulderberga, 2017), although other policies indirectly limit their possibilities in this regard.

It should be pointed out that increase in agricultural productivity in the EU, including, in particular, in the new Member States, may depend on the most eagerly supported directions of the EU agricultural policy (Mickiewicz and Pilvere, 2017; Mickiewicz et al., 2017), since agricultural subsidies and the RDP contribute greatly to investing in agriculture (Nipers et al., 2017; Pietrzykowski et al., 2011), which is also indicated by the set of variables included in agricultural development models (Zeverte-Rivza et al., 2017). Achievement of higher productivity of agriculture as a whole in a given country takes place slowly, because the system is very complex and it is not centrally coordinated, and effects of implementation of innovative solutions are not always known (Broring, 2008). The actions taken are those, which are associated with the lowest risk levels (Boehlje et al., 2011, Wicka et al., 2013). Despite these conditions, indicated by various authors, it has been observed that in the long-term perspective, total productivity depends on the agricultural policy to a very small extent; in fact, it is more dependent on weather changes (Fuglie et al., 2017).

In measurement of changes in agricultural productivity, the total factor productivity is one of the best tools. It takes into account the entire land, labour, equity and other material inputs engaged in agricultural production, comparing these to the total quantity of plant and animal production achieved. If total production is growing faster than inputs, the TFP increases. TFP differs from such productivity measures as yield or added value per employee, as it takes into account a wider scope of inputs used for production.

\section{Aim and methods}

The aim of this study is to compare changes in agricultural productivity in some of the new EU member states, achieved after year 1991, and to determine the significance of technical progress for these changes. The research tasks are as follows: 1) determination of changes in total agricultural productivity, 2) determination of change in the level of production inputs, 3) determination of relative significance of land, other production inputs and changes in TFP in generating growth of agricultural production. The analysed period encompassed years 1991 2014, that is, the period after the systemic transformation, and seven out of ten states, which acceded to the European Union in 2004. Slovenia, Malta and Cyprus were omitted as countries that had not been included in the former Eastern bloc before year 1991. The Czech Republic and Slovakia were considered jointly due to availability of data.

Source data for analysis was obtained from the United States Department of Agriculture (USDA) database, prepared on the basis of the data of FAO available on the Web page http://www.usda.gov. 
Total factor productivity (TFP) is defined as the ratio of change in total production to total expenditures. If total production (output) is represented by $Y$ and total expenditures (input) are represented by $X$, TFP can be presented as follows:

$$
\mathrm{TFP}=\mathrm{Y} / \mathrm{X}
$$

Where: $Y$ represents total production (output) and $X$ represents total expenditures (input).

Changes in TFP over time are found by comparing the rate of change in total output with the rate of change in total input. Expressed as logarithms, changes in equation (1) over time can be written as

$$
\frac{d \ln (T F P)}{d t}=\frac{d \ln (Y)}{d t}-\frac{d \ln (X)}{d t}
$$

which simply states that the rate of change in TFP is the difference between the rate of change in aggregate output and input. It is also possible to focus on a particular input, say land (which is designate as $\left.\mathrm{X}_{1}\right)$, and all other inputs $\left(\mathrm{X}_{\mathrm{j}}\right)$ decompose growth into the component due to expansion of land (extensifiaction) and after further decompose yield growth into the share due to TFP and the share due to using other inputs more intensively per unit of land.

$$
g(\mathrm{Y})=g(\mathrm{X} 1)+g(\mathrm{TFP})+\sum \mathrm{S}_{\mathrm{j}} g\left(\frac{\mathrm{X}_{\mathrm{i}}}{\mathrm{X}_{1}}\right)
$$

Where $\mathrm{g}$ - annual rate of growth in a variable and $S_{j}$ is share of $j$-th input.

Figure 1 gives a graphical depiction of the growth decomposition described in equation (3). The height of the bars indicates the growth rate of real output. Growth in real output is first decomposed into growth attributable to agricultural land expansion (extensification) and growth attributable to raising yield per hectare (intensification).

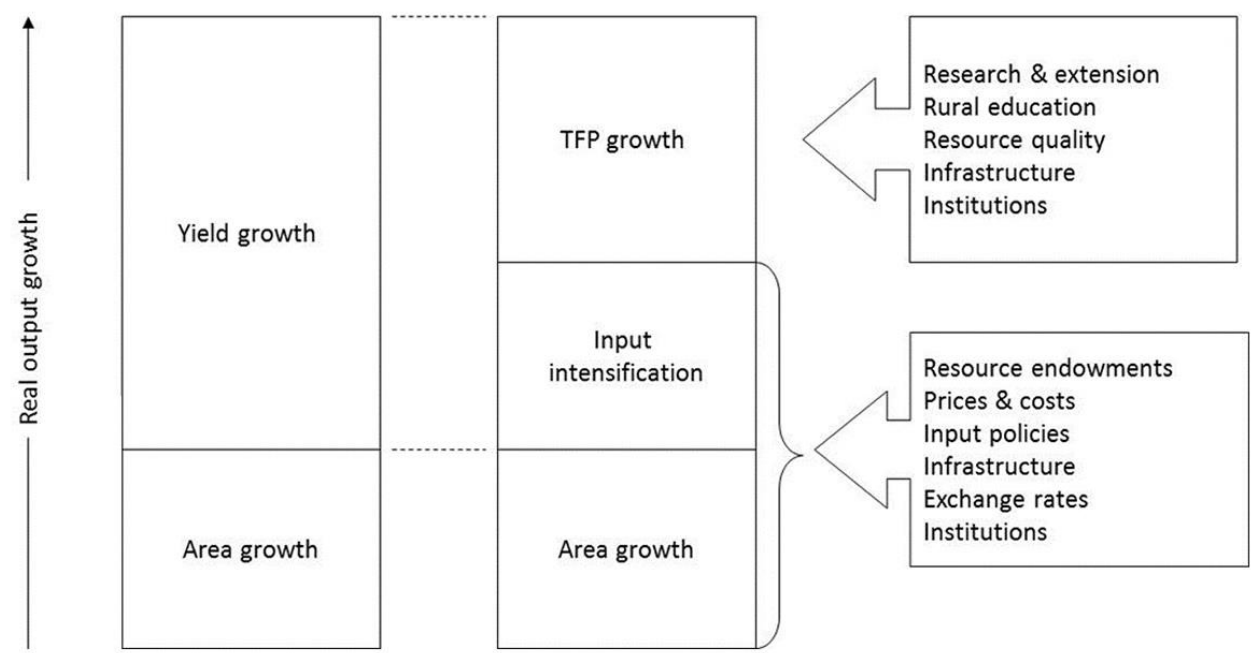

Source: Fuglie \& Rada, 2013

Fig. 1. Agricultural growth comes from increasing the use of land and other resources and/or from raising the productivity of those resources

\section{Research results and discussion}

Global agricultural production has increased since 1971 by more than $2 \%$ per annum. In the subsequent periods, increase in the area of farming land and increase in production means per hectare for production growth has been gradually losing significance. On the other hand, significance of TFP in overall production increase kept growing. If we assume that whole of yearly 
production increase is $100 \%$ then we can observe that share of TFP in such growth in years 19711990 was about $25 \%$; however, after year 1990, this share increased to almost $70 \%$ (Fig. 2).

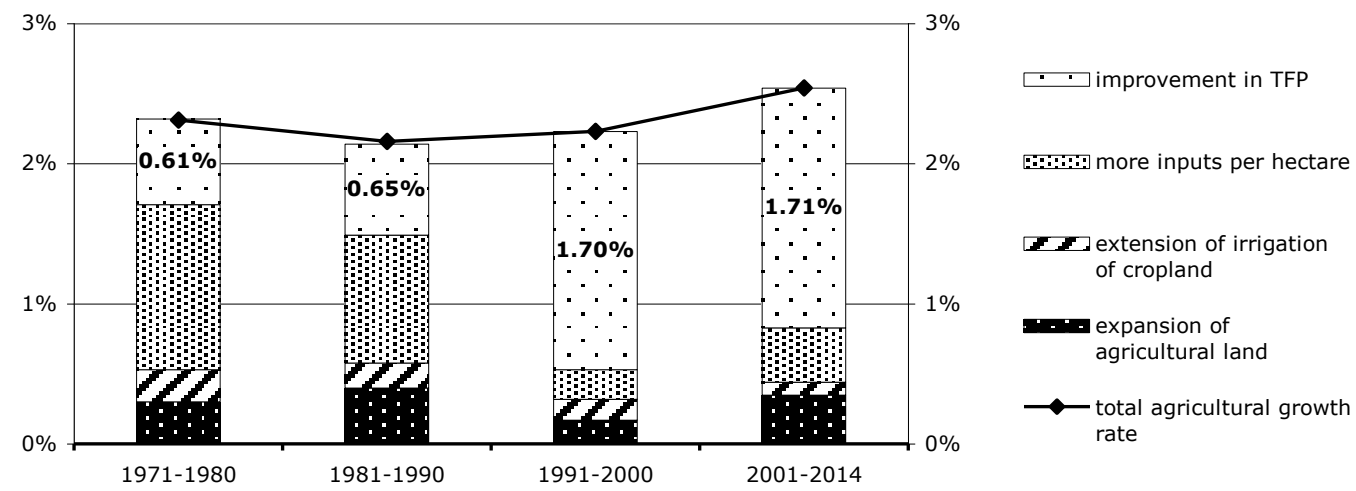

Source: USDA, Economic Research Service, data as of October 2017

Fig. 2. Sources of growth in global agricultural output, 1971-2014

The value of agricultural production in the analysed countries varied significantly depending on the country size. In Poland, agricultural production in 2014 amounted to USD 22.4 billion (constant USD 2004-2006), in Hungary - USD 6.7 billion, in the former Czechoslovakia - USD 6.2 billion. In the Baltic countries, the figures were as follows: USD 0.7 billion in Estonia, 1.1 billion in Latvia and 2.3 billion in Lithuania. In the examined countries, changes in total agricultural production after year 1991 varied; however, in all of them, there was a strong initial decrease in the production levels (Fig. 3). After year 1996, production stabilized. The lowest decrease in production was observed in Poland, then - in the Czech Republic and Hungary. In year 2014, in Poland, the real agricultural production level amounted to approximately $97 \%$ of production of year 1991. The highest decrease in real agricultural production was observed in Estonia - $44 \%$ and in Lithuania and Latvia - $33 \%$.

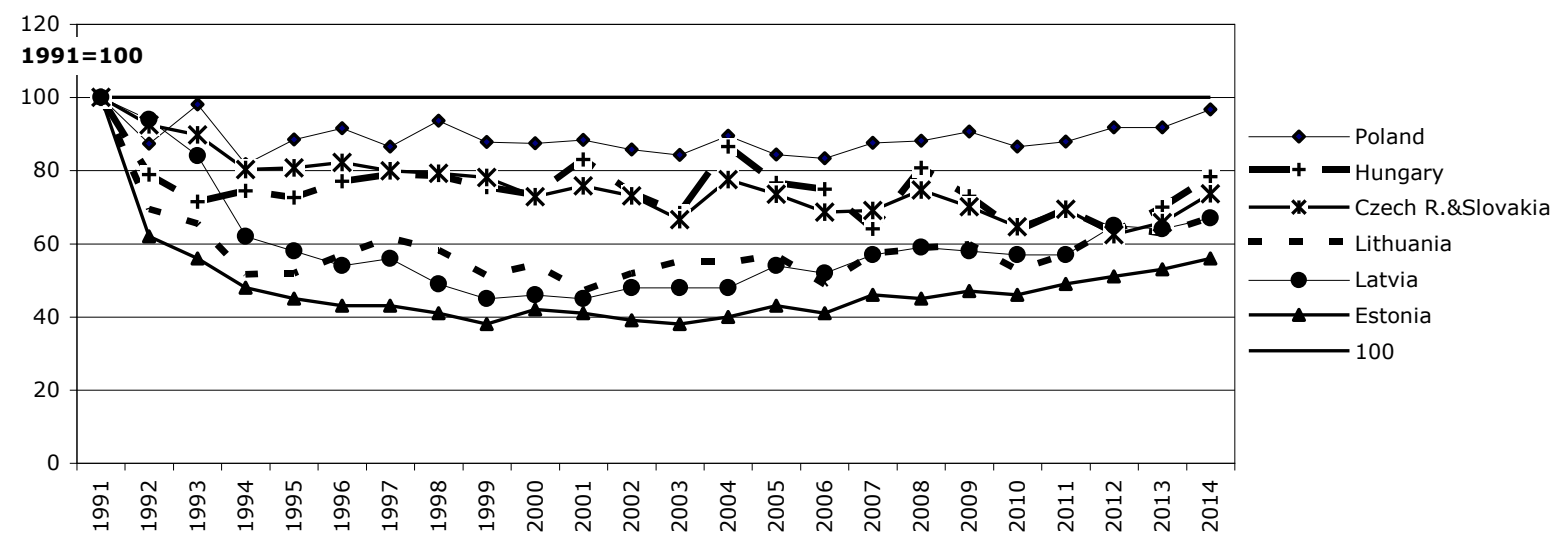

source: author's calculation based on USDA data

Fig. 3. Total agricultural production in period 1991-2014 (calculation based on prices in constant USD 2004-2006); 1991 = 100

A change in the size of agricultural production was due to a substantial reduction in the level of inputs, as well as exclusion of some parts of land from agricultural use. Figure 4 presents changes in the level of production input in agriculture in the examined countries. The level of inputs in agriculture (including land) decreased more than total agricultural output. The greatest decrease in production inputs was recorded in Latvia and Estonia - by more than $50 \%$, and the lowest - in Poland and Hungary: approximately $25 \%$. Decrease in the area of agricultural land in Estonia 
reached as much as $40 \%, 30 \%$ in Latvia, while in Poland, Hungary in Lithuania, it was about $10 \%$.

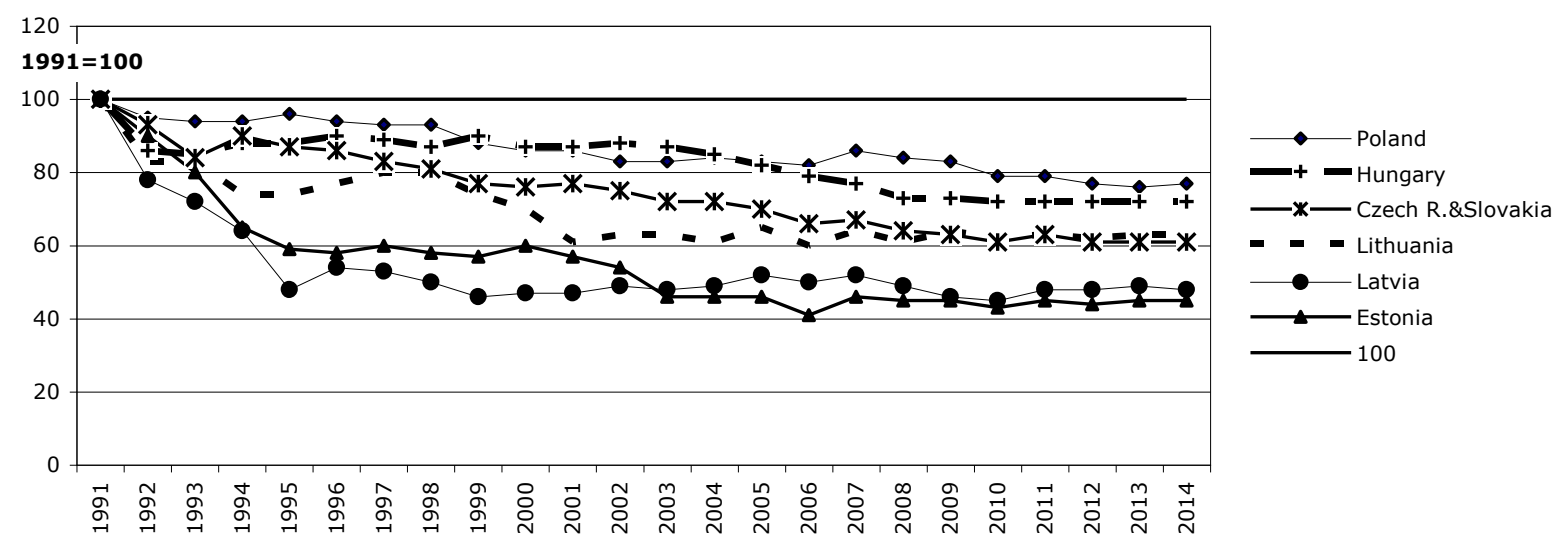

source: author's calculation based on USDA data

Fig. 4. Aggregate inputs in agriculture in period 1991-2014 (calculation based on prices in constant USD 2004-2006); 1991=100

Figure 5 presents the change in TFP in the analysed period for agriculture in individual countries. Until year 2014, the total TFP level in each of the analysed countries was higher in comparison with the base year 1991. The situation of Latvia should be mentioned separately. In this country, agriculture reached the highest level of productivity of resources, reaching increase of agricultural production, despite the production inputs did no grew. The most visible decrease in productivity was recorded in Lithuania in years 1994-2001. For all countries after year 2000, TFP increased in the subsequent years with some minor fluctuations. In the last year of the analysis (2014), total productivity of production factors in Latvia was higher by as much as $38 \%$ in comparison with data for year 1991. Increase above $20 \%$ was also recorded in Poland, the former Czechoslovakia and Estonia. In the remaining countries, it was 7 to $8 \%$. It should be noted, however, that in some countries, a substantial decrease in productivity was recorded in agriculture in the first years following the systemic transformation, reaching even $30 \%$.

Average annual change in TFP in the period of 1991 - 2014, estimated on the basis of the power function, amounted to $0.54 \%$ in Hungary, $0.70 \%$ in the former Czechoslovakia, around $1 \%$ in Poland and Latvia, $1.2 \%$ in Lithuania and as much as $2.3 \%$ in Estonia.

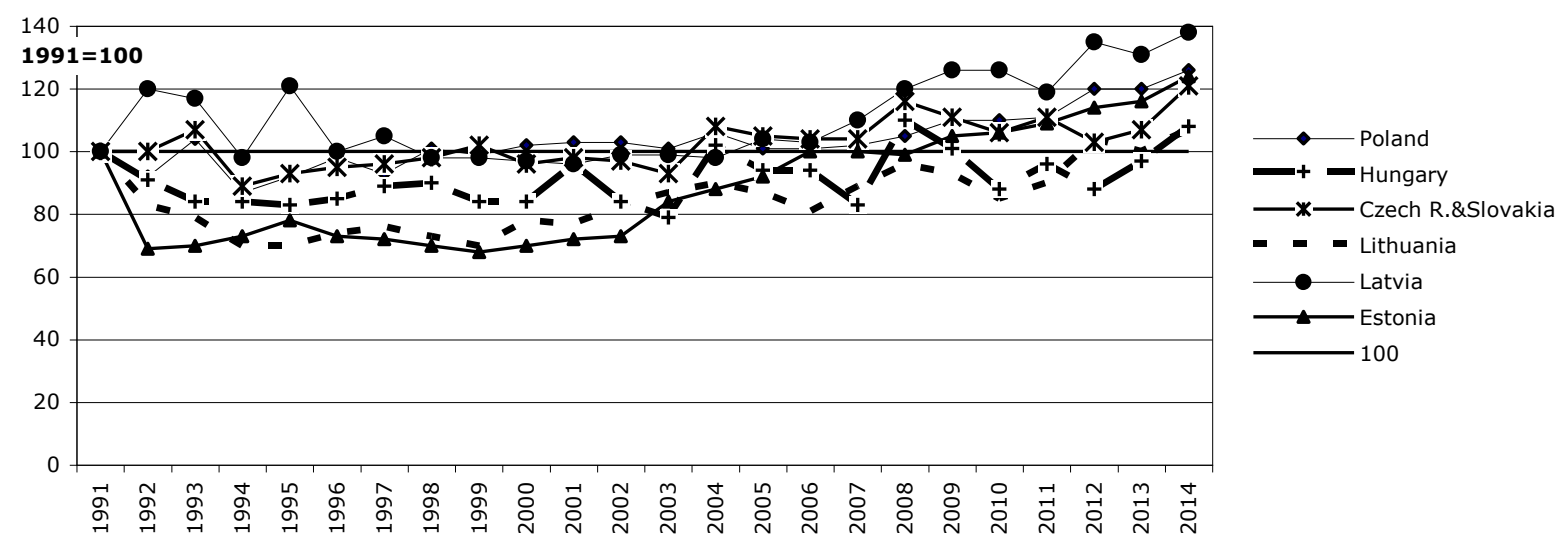

source: author's calculation based on USDA data

Fig. 5. Total Factor Productivity in agriculture in period 1991-2014, 1991=100 
Taking into account the opposite impact of individual factors, that is, decrease in the level of inputs, accompanied by increase in productivity of inputs, the structure of impact of key factors on changes in agricultural production was presented. Three factors were identified: land area, production intensity level and TFP. The results have been presented in Figure 6 .

In each of the countries presented, except Poland, there was a decrease in the area of arable land and a decrease in intensity of agricultural production in the examined period. The most significant decrease in arable land area was recorded in Estonia, Lithuania and Poland. In each of the countries examined, except Poland, agricultural production intensity also decreased, which was most visible in the Czech Republic and Slovakia. The observed increase in total factor productivity failed to compensate fully the decrease in expenditures and intensity, thus leading to reduction of the level of agricultural production. The most significant decrease in agricultural production was recorded in the Czech Republic and Slovakia $(-1.39 \%)$, and the lowest - in Poland $(-0.05 \%)$ (Fig. $6)$.

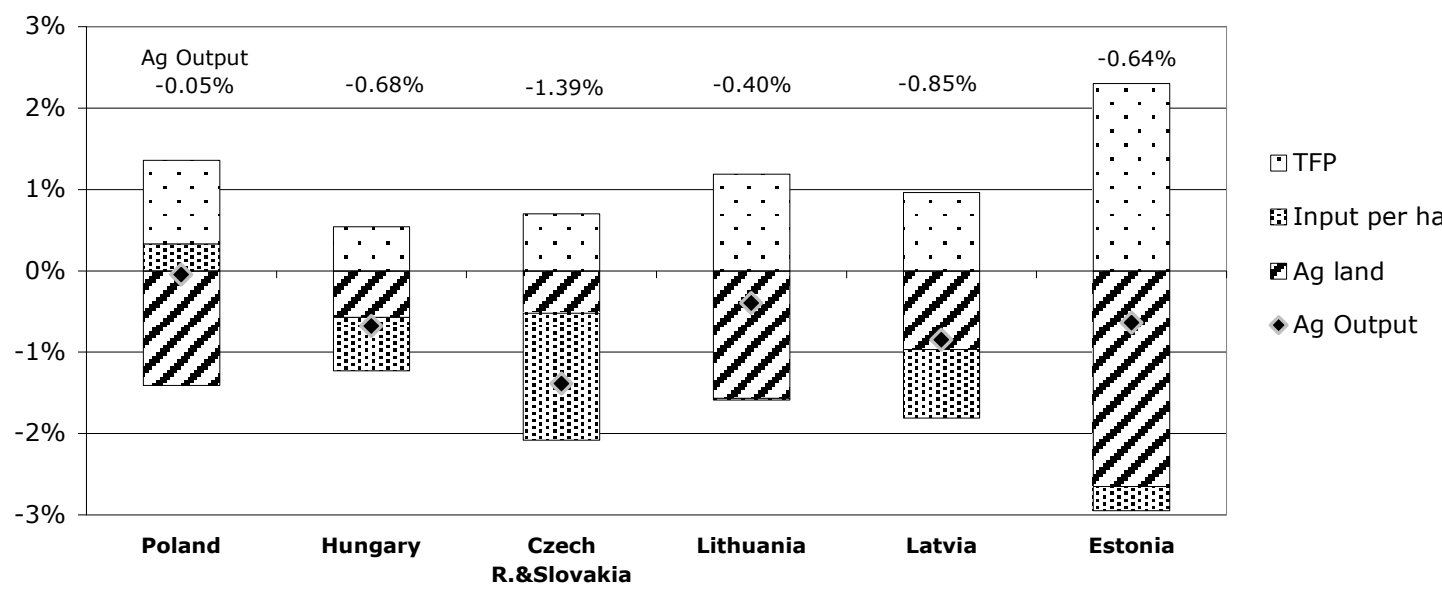

source: USDA, Economic Research Service, data as of October 2017

Fig. 6. Sources of growth in global agricultural output in percent annually, 1991-2014. CAGR of agricultural output in percent for each country is indicated high on the chart

In analysis of a shorter period, e.g. only years 2001-2014, there is a visible strong impact of TFP on agricultural production size. Technological change contributed to increase in agricultural production from $1 \%$ per annum in the Czech Republic and Hungary to more than $3 \%$ per annum in Estonia and Latvia. However, visible differences were recorded in terms of use of other production factors: in all Baltic countries, the area of farming land increased (from $0.6 \%$ annually in Estonia to $2.8 \%$ in Lithuania), while in the remaining countries, it decreased. In the Baltic countries, agricultural production increased in this period by more than $2 \%$ per annum, while in other countries it either decreased, or increased only slightly.

\section{Conclusions}

1) The growing global population and improvement of the standard of living results in increased demand for food. Thanks to progress in agriculture, this demand can be satisfied despite the limited availability of agricultural land.

2) The role of technical progress in increase in food production has been growing systematically. In years 1971-1990, the average annual global increase in agricultural production amounted to $2.2 \%$, and the share of technical progress in this phenomenon accounted for approximately $25 \%$. After year 1990, the production dynamics remained similar, while the contribution of increase in 
productivity reached almost $70 \%$. At present, TFP remains the most significant factor of production growth in agriculture.

3) In the analysed countries of Central and Eastern Europe after year 1991, a significant decrease in agricultural production was recorded due to reduction of farming land resources and production inputs. After year 2000, agricultural production started to increase; however, only in Poland it has reached the level similar to that of 1991 . In the remaining countries, it amounted to 60 to $80 \%$ of the level recorded in year 1991.

4) Average annual increase in total factor productivity (TFP) in years 1991-2014 was high in each of the countries examined, ranging from $0.54 \%$ in Hungary to as much as $2.3 \%$ in Estonia. On the average, TFP increase amounted to approximately $1 \%$ per annum. Increase in total factor productivity compensated 70 to $100 \%$ of decrease in production area and in the level of inputs. Nevertheless, full substitution of use of these factors by TFP was achieved only in Poland. After year 2000, the share of TFP in growth of agricultural productivity almost doubled in comparison with the 1990s, and in Estonia, Lithuania, Latvia and Poland, production increased despite lack of increase in the level of production inputs.

5) Technological progress in the analysed countries, as well as on the global scale, has played a dominant role in achievement of increase in agricultural production and effectiveness of other inputs. In these countries, decrease of production inputs in agriculture, reaching even $30 \%$, has been compensated by technological change. In the future, agricultural production may increase further even if the volume of resources used remains unchanged.

\section{References}

1. Alston, J., Andersen, M., James, J., Pardey, P. (2011).The Economic Returns to U.S. Public Agricultural Research. American Journal of Agricultural Economics, 93(5), pp. 1257-77. https://doi.org/10.1093/ajae/aar044

2. Boehlje, M., Roucan-Kane, M., Broring, S. (2011). Future Agribusiness Challenges: Strategic Uncertainty, Innovation and Structural Change. International Food and Agribusiness Management Review, 14(2), pp. 5382.

3. Broring, S., 2008. How Systemic Innovations Require Alterations Along the Entire Value Chain-the Case of Animal Derived Functional Foods. Journal of Chain and Network Science, 8(2), pp. 107-119.

4. Czyzewski, A., Kulyk, P. (2014). Relacja ziemia-praca w warunkach finansowego wsparcia rolnictwa na przykladzie wybranych krajow swiata i Unii Europejskiej-15 po 1986 r. (The Relation Land-Labour Conditioned the Financial Support of the Agriculture on the Example of Chosen Countries of the World and UE-15). Zeszyty Naukowe SGGW w Warszawie - Problemy Rolnictwa Swiatowego, 14(29) (2), 31-42

5. Czyzewski, A., Majchrzak, A., Smedzik-Ambrozy, K. (2017). Land Productivity and Its Prices in the Countries of EU-15 and EU-12. Economic Science for Rural Development, 46, pp. 228-228. Retrieved: http://llufb.llu.Iv/conference/economic_science_rural/2017/Latvia_ESRD_46_2017-228-233.pdf

6. Czyzewski, A., Staniszewski, J. (2015). Cenowe uwarunkowania zmian struktury czynnikow wytworczych w rolnictwie polskim w latach 1999-2013 (The Price Conditions and Changes of the Structure of Production Factors in Polish Agriculture in Years 1999-2013). Roczniki Naukowe Ekonomii Rolnictwa i Rozwoju Obszarow Wiejskich, 102 (4): pp. 7-17. Retrieved: http://sj.wne.sggw.pl/article-RNR_2015_n4_s7/

7. Czyzewski, A., Staniszewski, J. (2016). Zastosowanie regresji panelowej dla oceny produktywnosci i dochodowosci w rolnictwie krajow Unii Europejskiej po 2005 roku (The Use of a Panel Regression for the Assessment of Productivity and Profitability in The Agriculture of the European Union Countries After 2005). Roczniki Naukowe Ekonomii Rolnictwa i Rozwoju Obszarow Wiejskich, 103 (3), pp. 7-21. Retrieved: http://sj.wne.sggw.pl/article-RNR_2016_n3_s7/

8. Czyzewski, A., Staniszewski, J. (2017). Wydajnosc pracy jako przeslanka restrukturyzacji zatrudnienia w rolnictwie (Labor Productivity as a Premise to Restructure Employment in Agriculture). Zeszyty Naukowe SGGW w Warszawie - Problemy Rolnictwa Swiatowego, 17(32) (1), pp. 31-42. https://doi.org/10.22630/PRS.2017.17.1.3

9. Danilowska, A. (2015). Provision of Public Goods by Agriculture in Poland. Economic Science for Rural Development, 37, pp. 142-151.

Retrieved: http://llufb.llu.Iv/conference/economic_science_rural/2015/Latvia_ESRD_37_2015-142-151.pdf

10. Du, X., Zhang, X., Jin, X. (2018). Assessing the Effectiveness of Land Consolidation for Improving Agricultural Productivity in China. Land Use Policy, 70, pp. 360-367. https://doi.org/10.1016/j.landusepol.2017.10.051. 
11. Dudek, H.,Wicki, L. (2009). Factors Influencing Productivity of Cereals in Polish Agriculture. Economic Science for Rural Development, 20, pp. 79-88.

12. Esposti, R. (2011). Convergence and Divergence in Regional Agricultural Productivity Growth: Evidence from Italian Regions, 1951-2002. Agricultural Economics, 42, pp. 153-169. https://doi.org/10.1111/j.15740862.2010.00508.x

13. Filipiak, T., (2014). Zmiany czynnikow produkcji a ich produktywnosc w gospodarstwach warzywniczych (Changes in the Factors of Production and Productivity in Vegetable Farms). Roczniki Naukowe Ekonomii Rolnictwa i Rozwoju Obszarow Wiejskich, 101 (3), 51-65. Retrieved: http://sj.wne.sggw.pl/articleRNR_2014_n3_s51/

14. Franc-Dabrowska, J. (2013). Regional Diversification of Financial Situation of Agricultural Enterprises in Poland. Earth Bioresources and Life Quality, 4, pp. 1-15 [Online].

15. Fuglie, K., Clancy, M., Heisey, P., Macdonald, J. (2017). Research, Productivity, and Output Growth in U.S. Agriculture. Journal of Agricultural and Applied Economics, 49(4), pp. 514-554. https://doi.org/10.1017/aae.2017.13

16. Fuglie, K., Rada, N. (2013). Growth in Global Agricultural Productivity: An Update. Economic Research Service, USDA. Retrieved: https://www.ers.usda.gov/amber-waves/2013/november/growth-in-globalagricultural-productivity-an-update.

17. Fuglie, K., Wang, S., Ball, V. (eds.) (2012). Productivity Growth in Agriculture: An International Perspective. Wallingford, UK: CAB International.

18. Gardner, B. (2002). American Agriculture in the Twentieth Century: How It Flourished and What It Cost. Cambridge, MA: Harvard University Press.

19. Gemma, S., Bulderberga, Z. (2017). Smart Specialization Strategy in Latvia, Estonia and Lithuania. Economic Science for Rural Development, 45, pp. 71-78. Retrieved: http://llufb.Ilu.Iv/conference/economic_science_rural/2017/Latvia_ESRD_45_2017-71-78.pdf

20. Golebiewska, B. (2009). Efektywnosc wykorzystania nakladow materialowych w indywidualnych gospodarstwach rolniczych o zroznicowanym stopniu powiazan z otoczeniem (Efficiency of Material Outlays Utilisation at Individual Farms with Different Degree of Connections with the Surrounding Environment). Zeszyty Naukowe SGGW - Ekonomika i Organizacja Gospodarki Zywnosciowej, 73, pp. 95-104. Retrieved: http://sj.wne.sggw.pl/article-EIOGZ_2009_n73_s95/

21. Golebiewska, B. (2011). Significance of Connections with the Environment of Agricultural Farms in Poland for Their Production and Economic Situation. Economic Science for Rural Development, 24, pp. 40-49. Retrieved: http://llufb.Ilu.Iv/conference/economic_science_rural/2011/24_Production_and_Taxes.pdf\#page $=40$

22. Golebiewski, J. (2013). Changes in Competition Trends and Labour Productivity in the Marketing Chain of Foodstuffs. Economic Science For Rural Development, 32, pp. 178-183. Retrieved: http://llufb.Ilu.Iv/conference/economic_science_rural/2013/Latvia_ESR_32_2013-178-183.pdf

23. Grontkowska, A., Gebska, M. (2017). Wybrane zagadnienia przewozu zwierzat i ich zaladunku w gospodarstwie w ocenie rolnikow. Roczniki Ekonomii Rolnictwa i Rozwoju Obszarow Wiejskich, 104 (4), pp. 151-163. https://doi.org/10.22630/RNR.2017.104.4.40

24. Hayami, Y., Ruttan, V. (1969). Factor Prices and Technical Change in Agricultural Development. The United States and Japan, 1880-1960. Staff Paper P69-19, University of Minnesota: St. Paul.

25. Huffman, W., Evenson, R. (1993). Science for Agriculture: A Long-Term Perspective. 1st ed. Ames: Iowa State University Press.

26. Kasztelan, P. (2009). Substytucja czynnikow produkcji w wielkoobszarowych przedsiebiorstwach rolniczych (Substitution of Production Factors in the Large Scale Agricultural Companies). Roczniki Nauk Rolniczych, Seria G, 96(3), pp. 174-181. Available from: http://sj.wne.sggw.pl/article-RNR_2009_n3_s174/

27. Kesti, M. (2011). Rozwoj kapitalu ludzkiego oraz wiedzy w relacji do produktywnosci (Human Capital and Knowledge Development Connection to Productivity). Zeszyty Naukowe SGGW - Ekonomika i Organizacja Gospodarki Zywnosciowej, 88, pp. 27-40. Available from: http://sj.wne.sggw.pl/articleEIOGZ_2011_n88_s27/

28. Lenerts, A. Popluga, D., Rivza, P. (2017). Selection of Greenhouse Gas Emission-Reducing Measures with Analytical Hierarchy Process Approach: A Case Study from Latvian Crop Production Sector. Economic Science For Rural Development, 44, pp. 267-273. Retrieved: http://llufb.Ilu.Iv/conference/economic_science_rural/2017/Latvia_ESRD_44_2017-267-273.pdf

29. Mickiewicz, A., Mickiewicz, B., Jurczak, R., Lisiak, S. (2017). Process of Shaping of Institutional Support for Agricultural Sector in Poland. Economic Science for Rural Development, 44, pp. 116-125. Retrieved: http://llufb.llu.Iv/conference/economic_science_rural/2017/Latvia_ESRD_44_2017-116-125.pdf

30. Mickiewicz, B., Pilvere, I. (2017). Shaping the Common Organisation of Agricultural Markets in the New Programming Period (2014 - 2020). Economic Science For Rural Development, 45, pp. 159-167.

Retrieved: http://llufb.Ilu.Iv/conference/economic_science_rural/2017/Latvia_ESRD_45_2017-159-167.pdf

31. Nipers, A., Pilvere, I., Bulderberga, Z. (2017). Role of Support Payments in the Development of Territories in Latvia. Economic Science for Rural Development, 45, pp. 176-185.

Retrieved: http://llufb.Ilu.Iv/conference/economic_science_rural/2017/Latvia_ESRD_45_2017-176-185.pdf

32. Oliynyk, O. (2012). Wsparcie panstwowe a produktywnosc pracy w rolnictwie (An International Comparison of the Effect of Government Support on Agricultural Productivity). Roczniki Naukowe Ekonomii Rolnictwa $i$ Rozwoju Obszarow Wiejskich, 99 (3), pp. 70-76. Available from: http://sj.wne.sggw.pl/articleRNR_2012_n3_s70/ 
33. Orlykovskyi, M., Wicki, L. (2016). Polityka i programy wsparcia rolnictwa w warunkach stowarzyszenia i czlonkostwa Polski w Unii Europejskiej. Wnioski dla Ukrainy (Policy and Programs Supporting Agriculture in the Conditions of Poland's Association and Membership in the European Union. Applications for Ukraine). Wydawnictwo SGGW: Warszawa.

34. Orlykovskyi, M., Wicki, L., Zaburanna, L. (2017). Agriculture in Poland and Ukraine - Potential and Dynamics of Changes in Production. Zeszyty Naukowe SGGW w Warszawie - Problemy Rolnictwa Swiatowego, 17(32) (4), 326-338. https://doi.org/10.22630/PRS.2017.17.4.108

35. Pawlak, J. (2010). Rola mechanizacji w rozwoju rolnictwa (Role of Mechanization in the Development of Agriculture). Roczniki Nauk Rolniczych, Seria G, 97(2), 165-175. Available from: http://sj.wne.sggw.pl/article-RNR_2010_n2_s165/

36. Pietrzykowski, R., Wicki, L. (2011). Regionalne zroznicowanie wykorzystania srodkow z programow Wspolnej Polityki Rolnej na modernizacje rolnictwa (Regional Differentiation in Absorptionof CAP Funds on Agriculture Modernization). Roczniki Nauk Rolniczych, Seria G, 98(4), pp. 7-22. Available from: http://sj.wne.sggw.pl/article-RNR_2011_n4_s7/

37. Piwowar, A. (2017). Struktury rolne i produktywnosc rolnictwa w Grupie Wyszehradzkiej (Agricultural Structures and Productivity of Agriculture in the Visegrad Group). Zeszyty Naukowe SGGW w Warszawie Problemy Rolnictwa Swiatowego, 17(32) (1), 152-160. https://doi.org/10.22630/PRS.2017.17.1.14

38. Rubins, M., Pilvere, I. (2017). Development of Renewable Energy Policy in Latvia. Economic Science for Rural Development, 44, pp. 281-291.

Retrieved: http://llufb.Ilu.Iv/conference/economic_science_rural/2017/Latvia_ESRD_44_2017-281-291.pdf

39. Ruttan, V. (2002). Productivity Growth in World Agriculture: Sources and Constraints. Journal of Economic Perspectives, 16 (4),161-184.

40. Stevenson, J., Villoria, N., Byerlee, D., Kelley, T., Maredia, M. (2013). Green Revolution Research Saved an Estimated 18 to 27 Million Hectares from Being Brought into Agricultural Production. Proceedings of the National Academy of Sciences of the United States of America, 110(21), pp. 8363-8368. Retrieved: http://www.jstor.org/stable/42656728

41. Wang, S., Heisey, P., Schimmelpfennig, D., Ball, E. (2015a). Agricultural Productivity Growth in the United States: Measurement, Trends, and Drivers. Washington, DC: U.S. Department of Agriculture, Economic Research Service, Economic Research Report No. 189.

42. Wang, S., Heisey, P., Schimmelpfennig, D., Ball, E. (2015b). U.S. Agricultural Productivity Growth: The Past, Challenges, and the Future. Washington, DC: USDA, Economic Research Service.

43. Wicka, A. (ed.) (2013). Czynniki i mozliwosci ograniczania ryzyka w produkcji roslinnej poprzez ubezpieczenia (Factors and Options for Risk Reduction in Crop Production Through Insurance). Wydawnictwo SGGW: Warszawa.

44. Wicka, A., Wicki, L. (2016). Bio-Economy Sector in Poland and Its Importance in the Economy. Economic Science for Rural Development, 41: 219-228.

Retrieved: http://llufb.llu.Iv/conference/economic_science_rural/2016/Latvia_ESRD_41_2016-219-228.pdf

45. Wicki, L. (2008). Wykorzystanie postepu odmianowego w produkcji zboz w polskim rolnictwie (Influence of Biological Improvements Gained in New Varieties on Yields and Production of Cereals in Poland). Roczniki Nauk Rolniczych, Seria G, 94 (2), 136-146. Retrieved: http://sj.wne.sggw.pl/article-RNR_2008_n2_s136/

46. Wicki, L. (2010). Efekty upowszechniania postepu biologicznego w produkcji roslinnej (The Effects of the Biological Progress Dissemination in Plant Production). Wydawnictwo SGGW: Warszawa.

47. Wicki, L. (2016a). Wykorzystanie potencjalu plonowania zboz w produkcji rolniczej w Polsce (The Level of Utilization of Potential of Yielding of Cereals Species in Poland). Roczniki Naukowe SERiA, 18(5), pp. 267273. Retrieved: http://rn.seria.com.pl/rn/category/6-18-5.html?download=291

48. Wicki, L. (2016b). Zmiany produktywnosci czynnikow wytworczych w polskim rolnictwie (Changes in Factor Productivity in Polish Agriculture). Zeszyty Naukowe SGGW - Ekonomika i Organizacja Gospodarki Zywnosciowej, (116): pp. 149-160. https://doi.org/10.22630/EIOGZ.2016.116.52

49. Wicki, L. (2017a). Food and Bioenergy - Evidence From Poland. Economic Science for Rural Development, 44, pp. 299-305.

Retrieved: http://llufb.Ilu.Iv/conference/economic_science_rural/2017/Latvia_ESRD_44_2017-299-305.pdf

50. Wicki, L. (2017b). Postep w plonowaniu odmian pszenicy ozimej i zyta w doswiadczeniach odmianowych w Polsce (Changes in Yielding of Varieties of Winter Wheat and Rye in Variety Testing in Poland). Roczniki Naukowe SERiA, 19(4), pp. 224-230. https://doi.org/10.5604/01.3001.0010.5191

51. Wicki, L. (2017c). Poziom i zakres wsparcia upowszechniania postepu biologicznego w produkcji roslinnej w ramach dzialan Agencji Rynku Rolnego (The Level and Scope of Support of Biological Progress Dissemination in Crop Production in Poland Within the Measures of Agricultural Market Agency). Zeszyty Naukowe SGGW, Polityki Europejskie, Finanse i Marketing, 18(67), pp. 259-271. https://doi.org/10.22630/PEFIM.2017.18.67.38

52. Wysokinski, M., Baran, J., Florkowski, W. (2015). Concentration of milk production in Poland. Economic Science for Rural Development, 37, pp. 93-104. Retrieved: http://llufb.Ilu.Iv/conference/economic_science_rural/2015/Latvia_ESRD_37_2015-93-104.pdf

53. Zeverte-Rivza, S., Nipers, A., Pilvere, I. (2017). Agricultural Production and Market Modelling Approaches. Economic Science for Rural Development, 45, pp. 267-274.

Retrieved: http://llufb.Ilu.Iv/conference/economic_science_rural/2017/Latvia_ESRD_45_2017-267-274.pdf 